\title{
Universiteit
}

Leiden

The Netherlands

\section{An Elementary Approach to the Rule of Law}

Bedner, A.W.

\section{Citation}

Bedner, A. W. (2010). An Elementary Approach to the Rule of Law. Hague Journal On The Rule Of Law, 2(1), 48-74. Retrieved from https://hdl.handle.net/1887/18070

Version:

Not Applicable (or Unknown)

License:

Leiden University Non-exclusive license

Downloaded from: $\quad$ https://hdl.handle.net/1887/18070

Note: To cite this publication please use the final published version (if applicable). 


\title{
An Elementary Approach to the Rule of Law
}

\author{
Adriaan Bedner*
}

The past ten years have seen an avalanche of literature on the rule of law, but little agreement on a definition of the concept - if it is defined at all. The present article offers a conceptual framework to deal with this situation. Departing from the two main functions the rule of law intends to serve - protecting citizens against the state and against one another - it dissects the various definitions in use into elements. These elements are discussed one by one and arranged in three categories: procedural elements, substantive elements and control mechanisms.

The result may not only be helpful in structuring debates about the rule of law, but also in evaluating claims about the success or failure of 'rule of law development'. Finally, the article contains suggestions on how to use this framework as a starting point for interdisciplinary research into the rule of law.

\section{INTRODUCTION}

While its huge popularity in political and developmental discourse suggests otherwise, a short look at the literature demonstrates that the rule of law concept is not so easy to define. During the past decade many scholars attempted to determine what rule of law actually means, what it should mean, or at least what its core features are or should be. These efforts have greatly helped our understanding of rule of law, but none of them has yielded a definition acceptable to all. Rule of law definitions seem bound to vary over time, place, context, and from author to author. $^{1}$

* Senior lecturer at the Van Vollenhoven Institute at Leiden University. I am grateful to my colleagues at the Van Vollenhoven Institute for their encouraging comments, as well as to two anonymous reviewers.

${ }^{1}$ See for instance R. Peerenboom, 'Varieties of Rule of Law: An Introduction and Provisional Conclusion, in R. Peerenboom (ed.), Asian Discourses of Rule of Law: Theories and Implementation of Law in Twelve Asian Countries, France and the U.S., 2004, p. 1, B. Tamanaha, On the Rule of Law: History, Politics, Theory, 2004, pp. 3-4, or R. Kleinfeld, 'Competing Definitions of the Rule of Law', in Th. Carothers, Promoting the Rule of Law Abroad: In Search of Knowledge, 2006. 
According to Fallon this is not surprising, as rule of law is an 'essentially contested concept'. This means that the "true" meaning of the Rule of Law depends on the resolution of contestable normative issues' and 'disagreements are therefore to be expected'. ${ }^{2}$ Some of this contestation about the rule of law can be resolved by taking into account the national context in which the concept is used. For instance, it makes sense to consider a citizen's right to trial by a jury as an important element of the rule of law in a country with a commensurate tradition, while its introduction in a criminal law system with another history would require a complete and expensive legal-institutional overhaul without immediate benefit.

However, Fallon is right in pointing out that also within a single (national) context rule of law is contested. The problem with the ensuing debates - including the academic ones - is that it is often not clear what they are about, since they are often couched in rather general terms. ${ }^{3}$ This conceptual unclarity leads to confusion, hinders meaningful comparative socio-legal research, and jeopardises development projects claiming to enhance the rule of law. ${ }^{4}$ It is the latter problem in particular which breathes urgency to this matter and elevates it above the level of an academic dispute. Since the 1990s the rule of law has been at the vanguard of 'good governance' promotion in development co-operation, and billions of dollars have been spent on projects aimed at establishing it. Unfortunately the amounts of funding have not been matched by instances of success and arguably this is at least in part due to the absence of agreement on what exactly these projects are supposed to achieve beyond their immediate objectives. In the words of Thomas Carothers:

'the question of where the essence of the rule of law actually resides and therefore what should be the focal point of efforts to improve the rule of law remains notably unsettled. Rule-of-law practitioners have been following an institutional approach, concentrating on judiciaries, more out of instinct than well-researched knowledge. ${ }^{5}$

${ }^{2}$ R. Fallon, 'The Rule of Law' as a Concept in Constitutional Discourse', 97 Columbia Law Review 1 (2007), p. 6, quoted in J. Waldron, 'Is the Rule of Law an Essentially Contested Concept (in Florida)', 21 Law and Philosophy (2001). Waldron takes the issue even further, claiming that 'we are also unsure why we value [the rule of law]'. However, this argument does not affect my approach as I 'neutralise' the normativity of the rule of law by opting for the two functions' approach set out below.

${ }^{3}$ For the non-academic debate this is even worse. For an excellent of this point, see Waldron, n. 2 above.

${ }^{4}$ Cf., Peerenboom, 'Varieties of Rule of Law', p. 2.

${ }^{5}$ Th. Carothers, 'The Problem of Knowledge', in Carothers, Promoting the Rule of Law Abroad: In Search of Knowledge, p. 21. 
Hence, there are good reasons to look for an analytically sound approach which can resolve such problems, without having to give up the 'adaptability' of the rule of law concept. This essay aims to contribute to that purpose by offering a conceptual framework for structuring debates on the rule of law, mainly building on work done earlier by Peerenboom and Tamanaha. It may also be of use to evaluate the frameworks of 'rule of law'-indicators, which are used and developed at the initiative of donor agencies. And finally, it may function as a starting point for socio-legal research to render more effective projects supporting the rule of law.

\section{Two Functions of the Rule of Law}

A preliminary matter that needs to be clarified is whether the object of this inquiry is the rule of law as it has been developed in the common law tradition, or whether it also includes such equivalent notions as the rechtsstaat, état de droit, etc. Given the purpose of this essay, the obvious choice is to include such equivalents. Not only are rule of law and the rechtsstaat of continental origin often used interchangeably, ${ }^{6}$ it is precisely the purpose of this essay to indicate which features are generally attributed to all of them. Rule of law is thus used as shorthand for the English and American rule of law, the German and Dutch rechtsstaat, the French état de droit, the Indonesian negara bukum, etc.

This decision may suggest that this essay considers the rule of law as a nonessentialist or 'empty' concept. However, a solid common foundation exists to start an inquiry into the rule of law. There is indeed considerable disagreement about rule of law definitions, but virtually everyone agrees on the two main functions the rule of law serves.

The first one is to curb arbitrary and inequitable use of state power. The rule of law is an umbrella concept for a number of legal and institutional instruments to protect citizens against the power of the state. This function of the rule of law was first coined by Plato and Aristotle, subsequently lost for more than a thousand years and then 'rediscovered' and elaborated by religious scholars - notably Thomas Aquinas - during the Middles Ages. The core idea is that the sovereign is bound by law, an idea elaborated in many ways since. ${ }^{8}$

\footnotetext{
${ }^{6}$ See for instance R. Kranenburg, Het Nederlands staatsrecht, 1925.

${ }^{7}$ One can obviously list many more functions or objectives served by the rule of law, but these are all somehow related to these two core ones. See Peerenboom, 'Varieties of Rule of Law', p. 3 and the discussion of Kleinfeld in this essay. In this manner the following enquiry is not a mere 'anatomical' approach of the rule of law, as criticized by Martin Krygier, 'The rule of Law: Legality, Teleology, Sociology', in G. Palombella and N. Walker, Re-locating the Rule of Law, 2008, pp. 45-69, but comes closer to the teleological and sociological approach promoted by this author. See also the conclusion to this article.

${ }^{8}$ Tamanaha, On the Rule of Law, pp. 7-9 and 18-19.
} 
The second function does not go back to Greek philosophy but, in the words of Kleinfeld came in 'through the back door' during the Enlightenment.' It is to protect citizens' property and lives from infringements or assaults by fellow citizens. ${ }^{10}$

Whether this second function must be considered equally important as the first one has been the subject of much debate. Some authors have argued that currently there is a tendency to neglect the first 'core' function in favour of the second, and that we should not further inflate this second function, or even put it outside the context of the rule of law. ${ }^{11}$ Nonetheless, there are strong reasons to leave it in. The first is that it is central to many of the current discussions concerning the rule of law and development. Dropping it would be missing the point of many debates hung on the rule of law peg. An additional reason for giving it a central position is that human rights - considered by many to be an integral part of the rule of law - have increasingly been used as a defining standard for relations between citizens and their fellow-citizens, and not only between states and their citizens. The issue no longer is solely how the state treats its citizens, but also how citizens treat one another. For that matter, violence against women has become an integral part of international human rights regimes, with CEDAW perhaps the best-known example. ${ }^{12}$ This has important implications for states, which have to prevent citizens from infringing on the rights of their fellow citizens. Since many authors discuss such issues in rule of law terms it makes sense to consider the second function as central to the rule of law as well.

It is important to see that these functions tend to conflict. While Stephen Holmes - among others - has convincingly argued that limitations on state power actually increase the effectiveness of this power, ${ }^{13}$ states often feel that they need more of unfettered power than is actually good for them - and the argument often is that

${ }^{9}$ Kleinfeld, 'Competing Definitions of the Rule of Law', p. 40.

${ }^{10}$ This notion is more common to rule of law than to rechtsstaat definitions. For an overview of the historical distinction between the two see N.W. Barber, 'The Rechtsstaat and the Rule of Law', University of Toronto Law Review (2003), pp. 443-454, quoted in HiiL, 'Rule of Law Inventory Report', Academic Part, Discussion Paper for the High Level expert Meeting on the Rule of Law of $20^{\text {th }}$ April 2007, p. 7.

${ }^{11}$ E.g., J. Ohnesorge who warns the 'jurists' for losing their cherished rule of law concept to the 'economists', who tend to focus on property rights only J. Ohnesorge, 'The Rule of Law, Economic Development and Developmental States in Asia', in C. Antons, Law and Development in East and Southeast Asia, 2003, pp. 92-93.

12 The UN-Convention on Eliminating Discrimination Against Women (adopted in 1979).

${ }^{13}$ S. Holmes, Passions and Constraint: On the Theory of Liberal Democracy, 1995, in particular pp. 100-133. Holmes sets out his argument in an alternative reading of Jean Bodin. The core of the matter is that while normatively sovereign power is unfettered, empirically it can be effective only if it is felt as legitimate power by those subjected to it. The most effective means to achieve this is by some form of formal-rational organization of its exercise. 
they need to protect citizens from one another. This tension between governability and the aim of the rule of law to bind power is one of the problems always visible in debates concerning rule of law promotion. ${ }^{14}$

\section{Competing Definitions}

The distinctions between definitions of the rule of law basically reflect views on the desirability or the necessity to have particular 'instruments' in place to promote the twin functions discussed above, i.e., protecting citizens against the state and protecting one citizen from the other. Such choices are inspired by views on which instruments are best suited to attain an optimum balance between limitations on state power and protecting citizens' property and lives.

This raises a number of questions which are at the heart of the 'essential contests' about rule of law definitions. The first is which instruments potentially offer the best guarantees to protect citizens against the state and fellow citizens, and which connections exist between them. While the core instrument, to have the state bound by law, benefits every citizen and therefore is 'an unqualified human good', ${ }^{15}$ this does not apply to most others. Apart from the obvious question how the state must be bound by law, one may wonder how important is it to have an independent judiciary, how important is it to have human rights protected by a written constitution, and whether it makes sense to have an independent judiciary without human rights to protect. Answers to such questions are hard to provide, as they depend on the context of a given state or society. ${ }^{16}$ However, when contextualised it is possible to render them operational - at least to an extent and to subject the effectiveness of particular items to empirical testing. ${ }^{17}$

The second question is which of the two functions the rule of law is supposed to serve should be prioritised if they come into conflict. Is it possible to protect citizens against terrorist attacks without reducing their right to privacy? Should we

${ }^{14}$ In fact is was already present in the earliest projects within the Law and Development movement. See J.A. Gardner, Legal Imperialism: American Lawyers and Foreign Aid in Latin America, 1980. See also G. O'Donnell, 'Horizontal Accountability in New Democracies', 9 Journal of Democracy 3 (1998), at p. 2.

${ }^{15}$ E.P. Thompson, Whigs and Hunters: The Origins of the Black Act, quoted in Tamanaha, On the Rule of Law, p. 137.

${ }^{16}$ Cf., Peerenboom, 'Varieties of Rule of Law', p. 11.

${ }^{17}$ Some scholars prefer to prevent such 'internal' comparison by leaving out some instruments altogether. For instance, they prefer not to include democracy or human rights within their definition of the rule of law, which allows them to draw conclusions concerning the rule of law without having to address the ins and outs of democracy as well. An example of a forceful argument along these lines is HiiL 2007. Not surprisingly, this approach was criticized by some of the participants at the meeting where the report was presented, who favoured a more inclusive, 'aspiring' definition. 
not give a broad, ill-defined mandate to the state to make sure that it can effectively promote the rights of cultural minorities?

This is a normative matter and escapes cross-case empirical evaluation. Being an issue of ideological preference and political choice it belongs to the realm of political philosophy rather than socio-legal studies, although the latter can be helpful in predicting or examining the consequences of such choices. While some people may prefer to sacrifice efficiency of the state in order to realise maximum protection against it, others would rather increase efficiency at the expense of protection. Socio-legal studies may assist in providing materials on which to judge the likely effects of policy choices in a given context, but they can never justify the choice.

An important reason to pay attention to this issue is that many donor agencies promoting rule of law development pretend to promote something that is 'beyond politics'. Their version of the rule of law is presented as a 'universal good', while much of it actually is not. Some donors even leave out certain 'core' instruments of the rule of law competing with their own, usually economic objectives. This serves their ends better than to admit that various rule of law instruments may actually compete. ${ }^{18}$

Some authoritarian regimes take this matter even further, stretching the definition of rule of law so far that one wonders whether anything is left of it. They may dismiss central rule of law components such as the independence of the judiciary, but still claim that they adhere to the rule of law doctrine in its entirety. This can be easily explained from the universal appeal of the word 'rule of law'. Fully rejecting the rule of law means taking a risk regarding a regime's internal and external legitimacy, just as completely rejecting democracy. It is politically advantageous to claim that you stay within the boundaries of the rule of law, if only a 'different kind' of rule of law. ${ }^{19}$ Governments will always find constitutional lawyers prepared to underpin such claims with theoretical arguments.

The main conclusion we may draw from this short discussion is that in contrast to the degree of unanimity on rule of law functions, the common ground of definitions is rather thin. It will be impossible to find a definition pleasing all and therefore opting for yet another definition is not likely to bring much clarity to rule of law debates.

${ }^{18}$ Cf., Kleinfeld, 'Competing Definitions of the Rule of Law', pp. 32-34 on this point. She argues that at the basis of the alternative definition of donor agencies involved in rule of law projects is that they offer a practical focus for them. Although that may be true to some extent, I think Ohnesorge is right in pointing out that underlying this focus is an agenda aimed at economic development - thus valuing the second rule of law function over the first one. See for a critical analysis on this point J. Faundez, 'The Rule of Law Enterprise - Towards a Dialogue between Practitioners and Academics', 2005, CSGR Working Paper No. 164/05.

19 Tamanaha, On the Rule of Law, p. 3; Peerenboom, 'Varieties of Rule of Law', p. 1. 


\section{Dissecting Rule of Law Definitions}

If we depart from the two functions outlined above, we should be able to find an alternative solution to the problems mentioned at the outset of this essay. The one proposed is relatively simple: instead of talking about 'the rule of law' as a monomorphous concept for analytical purposes we should dissect it into elements.

This is not a new idea. Various authors have made attempts at classification based on what could be labelled elements, ${ }^{20}$ but most of them offer no systematic approach and do not clearly explain why they include certain elements while dismissing others.

There have been two approaches to achieve a more systematic classification. ${ }^{21}$ The first has been to make the now familiar distinction between formal and substantive versions of the rule of law - formal versions going back to the Greek tradition and substantive to the Lockean fundamental rights approach. Formal versions are concerned with law as an instrument and a basis of government, but are silent on what the law should regulate. Substantive versions, on the other hand, set standards to the contents of a norm, which should be morally justified.

The second approach to classification builds on the insight that rule of law definitions range from restricted (thin) to elaborate (thick) and that there is some sequence in this. An example of a thin definition is the following one by Raz:

The rule of law means literally what it says: the rule of laws. Taken in its broadest sense this means that people should obey the law and be ruled by it. ${ }^{.22}$

Thicker definitions, generally include the thin definition, but add to it. This can be seen, for instance, in the following, rather elaborate one by Thomas Carothers:

'The rule of law can be defined as a system in which the laws are public knowledge, are clear in meaning, and apply equally to everyone. They enshrine and uphold the political and civil liberties that have gained status as universal human rights over the last half-century. In particular, anyone accused of a crime has the right to a fair, prompt hearing and is presumed innocent until proved guilty. The central institutions of the legal system, including courts, prosecutors, and police, are reasonably fair, competent, and efficient. Judges are impartial and independent, not subject to political influence or manipulation. Perhaps most important, the government is embedded in a comprehensive legal framework, its officials accept that the law will be applied to their own conduct, and the government seeks to be law-abiding. ${ }^{23}$

${ }^{20}$ E.g., B. Hager, 'The Rule of Law : A Lexicon of Policy Makers', 2000.

${ }^{21}$ On this matter, see Tamanaha, On the Rule of Law, in particular p. 91.

${ }^{22} \mathrm{~J}$. Raz, 'The Rule of Law and its Virtue', in Raz, The Authority of Law: Essays on Law and Morality, 1979, pp. 210-232.

${ }^{23}$ Carothers, Promoting the Rule of Law Abroad, p. 4. 
Both Randall Peerenboom and Brian Tamanaha have used these two classifications to produce overviews of elements in formal and substantive versions. ${ }^{24}$ This essay further refines their models by paying separate attention to controlling mechanisms and by presenting them in a more clear-cut form that can be readily applied. This 'elementary rule of law model' thus builds on the 'formal-substantive' distinction and the 'thin-thick' continuum.

However, before elaborating this, we first need to consider another approach promoted by Kleinfeld. She distinguishes between means and ends of the rule of law and has argued that it makes more sense to take the ends as the distinguishing feature, instead of the means. According to Kleinfeld there are five ends: government bound by law, equality before the law, law and order, predictable and efficient justice, and lack of state violation of human rights. While her perspective is original, Kleinfeld's categories suffer from the same lack of specificity as the formal-substantive and the thin-thick distinctions. They are moreover not broad enough to incorporate elements of the rule of law which are frequently argued to be part of it, for instance democracy. More problematic still is that Kleinfeld's claim that her categories cannot be reduced one to the other is unconvincing. For instance, 'lack of state violation of human rights' likely requires that the government is bound by law and that citizens are equal before the law. ${ }^{25}$

In fact, Kleinfeld's ends can be easily related to the two functions, mentioned earlier, with government bound by law, equality before the law and lack of state violation of human rights as outcomes of the 'protection of citizens against the state'-function. Law and order, and predictable and efficient justice are related to the 'protecting citizens from each other'-function. The means Kleinfeld presents to these ends fit therefore well into the scheme that will now be outlined.

The development of this model consists of three steps. Underlying the approach is a thorough analysis of the concepts of rule of law in the literature. ${ }^{26}$ This first step is purely heuristic: its argument is not that certain elements ought to be part of the rule of law concept, but rather which elements are claimed to be part of it according to the literature.

The second step has been to classify the elements found in three categories. These are the well-known categories of formal and substantive elements, but for the sake of clarity a third category has been added. Usually subsumed under formal elements, 'control mechanisms' are of such a different nature and so important that they should have their own heading.

${ }^{24}$ Peerenboom, 'Varieties of Rule of Law', pp. 1-13, Tamanaha, On the Rule of Law, p. 93.

${ }^{25}$ Kleinfeld, 'Competing Definitions of Rule of Law', pp. 34-46.

${ }^{26}$ The review article by Marianne Termorshuizen. M. Termorshuizen, 'The Concept of Rule of Law', Jentera: Jurnal Hukum, Vol. 2 (3), 2004, pp. 77-119 has been helpful as a starting point for this purpose. 
The result of this is a rule of law conceptual framework that accommodates the rule of law concepts in use. This framework constitutes the basis for the third and final step, which provides a point of departure for rule of law research. It consists of adding questions to each element. They are partly of a legal nature and partly empirical and must be further refined, 'broken down' and attuned to the case or legal field studied.

This third step takes us to the last issue that needs to be addressed before expounding the model. It concerns the distinction between norm and fact. The matter is not so much that there would be disagreement about the question whether the rule of law is in place when a state is bound only legally, not in practice, or that the rights of its citizens are solely guaranteed on paper. Anyone will agree that a state not following its own rules is not a rule of law state. However, most - if not all - definitions also presuppose that citizens generally obey the law as well for the rule of law to be in place, even if it addresses states in the first place.

If we look at the first function, this condition seems superfluous. To protect citizens against the state does not require citizens to obey the law. One exception would be that citizens fail to use the means made available to them by the law to offer them such protection, but that seems rather far-fetched. However, if it comes to the second function, the result is different. If citizens do not follow the law intended to protect their fellow citizens from assaults on their lives and properties, it means that the state fails to realise this function. It therefore seems correct to look at citizens' obedience to the law as well when trying to measure the elements of the rule of law intended to serve the second function.

The following sections will shortly discuss the elements per category.

\section{$1^{\text {st }}$ Category: Procedural elements}

- Rule by law

- State actions are subject to law

- Formal legality (law must be clear and certain in its content, accessible and predictable for the subject, and general in its application)

- Democracy (consent determines or influences the content of the law and legal actions)

\section{Rule by law}

The category of procedural elements is concerned with the mode of governing and its legality. Present in any definition of the rule of law - even if only implicitly - is the first element of that category, which is that the state rules by law. The origin of this element as a separate part of the rule of law is not quite clear, since the earliest thinkers on rule of law as Plato and Aristotle were more concerned with 
the issue of the ruler being subject to the law, ${ }^{27}$ which is the next element. However, when Joseph Raz writes that 'the rule of law means literally what it says: the rule of laws', ${ }^{28}$ he is referring to this demand in the first place. Law(s) here should be understood as general rules and not as individual, arbitrary decrees. Moreover, rule by law demands at least a minimum degree of equality before the law.

'Rule by law' is commonly contrasted with 'rule by men', which carries with it the connotation of arbitrariness. ${ }^{29}$ In this sense rule by law is indeed the ultimate foundation of any attempt at curbing the exercise of state power. On the other hand, 'rule by law' is often juxtaposed with 'rule of law', conveying a rather negative meaning upon it. It in fact suggests that the state has law at its disposal as a powerful weapon without being subject to any restraint it inherently imposes. ${ }^{30}$ However, if one considers the situation that the government rules by individual decree only, it becomes clear that the requirement of rule by law is vital. A state such as the People's Republic of China comes close to adhering to this thinnest of rule of law versions ${ }^{31}$ and it is not difficult to see the advantage when we compare it to the situation during the Cultural Revolution.

Rule by law furthermore already implies that law should in principle be general in its content and that it should be known. The need for law being general becomes particularly clear from critiques on regimes that 'rule by exception'. In this situation general laws are set aside to make way for individual decrees, which removes the guarantee for certainty present in the demand of rule by law. The work done on the 'rule by exception' also indicates that rule by law can be undermined in a legal manner. ${ }^{32}$ That the state subverts this element if it acts without any legal basis, for instance by using vigilantes to remove citizens from their land, goes without saying, but undermining its own general rules by deploying individual decrees as it pleases may produce similar results.

A final note is that one should not underestimate how useful rule by law may be for a ruler. Rule by law is the first step towards legitimacy based on rationallegal government. Using general rules is moreover indispensable for governing over larger numbers of people in order to create clarity and stability where selfregulation is not wanted or overruled. Any case of state building at some point

${ }^{27}$ Tamanaha, On the Rule of Law, pp. 8-9.

${ }^{28} \mathrm{Raz}$, 'The Rule of Law and its Virtue', pp. 210-232.

${ }^{29}$ See for instance D. Ivison, 'Decolonizing the Rule of Law: Mabo's Case and Postcolonial Constitutionalism', Oxford Journal of Legal Studies, 17 (2007) p. 262.

${ }^{30}$ Tamanaha, On the Rule of Law, p. 92.

${ }^{31}$ For a more nuanced account, see R. Peerenboom, 'Competing Conceptions of Rule of Law in China', in Peerenboom, Asian Discourses of Rule of Law: Theories and Implementation of Law in Twelve Asian Countries, France and the U.S., pp. 113-145.

${ }^{32} \mathrm{~K}$. Jayasurya, 'The Exception Becomes the Norm: Law and Regimes of exception in East Asia', 2 Asian-Pacific Law \& Policy Journal 1 (2001), pp. 108-124. 
requires introducing rule by law, no matter how partial or awkward these attempts may look from a contemporary perspective. ${ }^{33}$

Similarly, Shapiro has pointed out how in dispute resolution consent of the parties about the rules to be applied and consent about the third party deciding the dispute have been substituted for law and office. These measures are required for the ruler to be able to get a grip on society by having disputes decided along the lines set out by the ruler. This also implies that any form of centralised authority will know a certain degree of rule by law. ${ }^{34}$

\section{State actions are subject to law}

The second element in the procedural category can be labelled the common core of all rule of law definitions. It first adds to the 'rule by law'-element by requiring a legal basis for every government act, the so-called principle of legality. Lawmaking also needs such a basis. Second, it demands that the government obey its own rules. As already stated, this requirement goes back to Plato and Aristotle and is strongly associated with the German concept of 'Rechtsstaat' as set out in its 'final' form by Carl Schmitt, with its lack of substantive and democratic elements. ${ }^{35}$ Limited originally by the idea that the sovereign can never be subject to law, since he can change the law as he pleases, later on procedural demands set to law, democracy, and ideas about natural law have managed to overcome this problem.

The demand that every state action has a legal basis can be rendered meaningless if this legal basis lacks specificity. A traditional area of contestation here is the issue of discretionary power, perhaps better expressed in the German notion of 'freies Ermessen'. Freies Ermessen attributes the government scope to freely determine its policies without having to account for them in any legal manner. This recognises the impossibility and undesirability that the legislator determines every

${ }^{33}$ See for instance A. Huxley, 'Positivists and Buddhists: The Rise and Fall of Anglo-Burmese Ecclesiastical Law', 26 Law \& Social Inquiry 1 (2001), pp. 113-142 on Burmese law, or J. Ball, Indonesian Legal History 1602-1848, on Javanese law. As rightly pointed out by an anonymous reviewer, this point reminds one of the work of Nonet and Selznick on types of law (or rather legal systems), viz. repressive, autonomous and responsive law Law and Society in Transition: Toward Responsive Law, 1978. The type of law referred to here is repressive law, but one should note that, as Nonet and Selznick argue, even repressive law is defined in terms of legitimation rather than sheer coercion. The next element discussed means a move towards autonomous law, while the substantive law is associated with the rights-approach discussed under the next category.

${ }^{34}$ M. Shapiro, Courts: A Comparative and Political Analysis, 1981. This is very clear from the history of colonial expansion; from the most limited form of British 'repugnancy clause' to the myriad categorization of legal orders in the Netherlands Indies. See for examples, W.J. Mommsen and J.A. de Moor, European Expansion and Law: The Encounter of European and Indigenous Law in $19^{\text {th }}$ - and $20^{\text {th }}$ Century Africa and Asia, 1992.

${ }^{35}$ C. Schmitt, Verfassungslebre, 1928. 
government action in detail beforehand, but on the other it creates the danger that the government will act in an arbitrary manner. ${ }^{36}$ Just as with the issue of being subject to the law, this problem has been tackled by jurists with the requirements to law's qualities inherent in the next element in this category and such administrative law concepts as principles of proper government.

The other problem with legality concerns so-called 'open concepts' in the law, such as 'the public interest', the 'common good' and others, which can be filled in by the government according to its own wishes and preferences. Probably no notion has been misused as often as that of the 'common interest', although it is impossible to altogether dispense with it or its equivalents. Just as the concept of freies Ermessen, discretionary power points at the fact that 'law' is too general a notion if we want meaningful checks on state power. The simple postulate that state actions should be subject to law is too broad to guarantee effective accountability. Therefore this notion is closely intertwined with the next element, which specifies what the law should be.

Legality can also be subverted by the state by introducing laws, which provide a legal basis for certain behaviour retroactively. This does not refer to the more general understanding of the principle of non-retroactivity, meaning that citizens' behaviour can be punished based on rules introduced after the event. It rather resembles the 'rule by exception' in that it provides a legal justification of state behaviour where the state acted without a basis in law. It is an issue not often paid attention to, but a fundamentally problematic way by which the state can loosen the ties of law.

There is another side to the principle of legality, which does not involve the use of law and can only to a limited extent be countered by law. It also concerns the requirement that the government in practice always acts on a legal basis, but is more difficult to resolve than the previous problem in that it does not even pretend legality by legalising behaviour retroactively. It involves both the situation that state officials themselves act without a legal basis and the situation that the state uses 'ordinary citizens' for this purpose, for example vigilantes. Of course one may establish legal rules and procedures to be followed to call the state to order on this matter, but if such behaviour is widespread even the most 'liberal' procedures applied by the most independent of judiciaries cannot control it. In the end it is the behaviour of state bodies themselves which is decisive. In most, if not all rule of law conceptions this is a major litmus test to establish whether a state can be labelled as obeying the rule of law.

This also applies to the matter of the state following its own rules and procedures. No matter how obvious, because the rule of law is traditionally a legal con-

\footnotetext{
${ }^{36}$ See, e.g., N. Wimmer, Dynamische Verwaltungslehre: Ein Handbuch der Verwaltungsreform, 2004, p. 198 et seq.
} 
cept this 'practical' side of rule of law is often disregarded. On the other hand, those developing rule of law indicators may lose sight of the legal issues and only focus on state practices. ${ }^{37}$ Particularly in this case it is important to distinguish between the legal and the empirical sides of the rule of law concept. ${ }^{38}$

\section{Formal legality}

As already indicated under the previous headings, law must conform to certain requirements if it is to be effective in restraining the exercise of power. Formal legality enables citizens to plan their behaviour, as they can predict how the state will respond. In fact, the previous two elements are meaningless to a large extent if formal legality is not in place as well.

While formal legality has a long history in fields as criminal law, where it provides the fundaments for the state's mandate to punish citizens, more recently theorists have come to focus on its importance for citizens' behaviour in the economic sphere. This means a shift from the first to the second function of the rule of law. It goes back to Max Weber, who was the first to write extensively on the importance of formal-rational law for economic behaviour, but in fact the jurists who during the Roman Empire elaborated and fine-tuned the rules of civil law were the forerunners of this idea.

The idea that formal legality in combination with the right to property and an independent judiciary, elements of the other two categories, leads to economic development has been extremely influential in international donors' circles and accounts for many projects conducted in this field. It is true indeed that for a modern state formal legality can be a very powerful device to introduce the certainty required for economic development, with Singapore perhaps as the most convincing example. However, there are also other ways to certainty, as there are ways to legitimacy other than formal-rational.

Nonetheless, it is generally agreed that formal legality may serve this goal well in any political system and arguably not only in modern states where clear codified rules offer the best guarantees for transactions between people not tied to each other by family or clan relations. The question is whether it can be achieved in other ways than by codifications and case law. Although it is beyond this essay to go further into this question, there are many examples of such systems which

${ }^{37}$ An example is D. Kaufmann, A. Kraay, and P. Zoidó-Lobaton, 'Agregating Governance Indicator', World Bank, http://www-wds.worldbank.org/external/default/WDSContentServer/IW3P/ IB/1999/10/23/000094946_99101105050593/additional/115515322_20041117135531.pdf.

${ }^{38}$ The most sophisticated rule of law indicators developed so far do take good account of this matter. See M.A. Agrast, et al., 'The World Justice Project Rule of Law Index: Measuring the Rule of Law around the World', see www.worldjustice.org. 
have been effective - and not in small-scale societies only. ${ }^{39}$ None the less, under conditions of stress, whether caused by migration, political turmoil, or other reasons, published codes and case law do seem the most likely way to achieve this, in particular on a larger scale. ${ }^{40}$

This applies certainly when it comes to bridle the state. The vaguer the rules, the more difficult this is. It is no wonder that the only nation without a written Constitution in the world is the United Kingdom, where the process to develop an equivalent set of rules to achieve state accountability started at a very early point in history and is accordingly well-rooted. ${ }^{41}$ In this sense formal legality indeed qualifies as a 'universal human good'. As Thompson also noted, 'it is inherent in the especial character of law, as a body of rules and procedures, that it shall apply logical criteria with reference to to standards of universality and equity. ${ }^{42}$ In other words, formal legality is somehow inherent in the idea of law itself.

Just as with the previous two elements, there is a legal and an institutional side to formal legality. Determining whether rules are clear and consistent is probably the essence of legal scholarship, just as making the law accessible. There are obviously many debates about the proper way of achieving this, for instance whether law must be written, codified, restated or produced through case law, but basically all these methods may be used to produce clear, certain, accessible and stable law. In any legal system these will be the points of departure for jurists, whether they are compiling a code, passing a judgment, or making a contract.

This implies an important institutional requirement for formal legality, being the existence of a legal profession which shares the same outlook on law. If serious divides exist among them, inevitably problems regarding formal legality will arise. This also to some extent explains the problems with legal transplants, if these have not been properly 'tailored' to the conditions of the receiving country. ${ }^{43}$

However, before the legal profession can do its work, certain basic conditions have to be fulfilled. Thus, if case law is not published, it cannot be reordered, and

${ }^{39}$ Japan is probably the best-known example.

${ }^{40}$ However, the process of transition will almost always be protracted, painful and problematic. Imposing 'alien' rules on a given society has always been highly problematic, as has become more than clear from studies on colonial societies, but also from those about France in the $18^{\text {th }}$ and $19^{\text {th }}$ centuries. On the other hand, codifying local rules is also a delicate activity and will inevitably spur disputes and reframe the power relations within that society. Unfortunately, the road in between of providing non-binding 'restatements' of customary law, as attempted by Van Vollenhoven in the Netherlands Indies has proven very difficult too with regard to its application.

${ }^{41}$ On the importance of constitutions in this respect, see G. Sartori, Comparative Constitutional Engineering: An Inquiry into Structures, Incentives and Outcomes, 1997.

42 Thompson, Whigs and Hunters: The Origins of the Black Act, at p. 262.

${ }^{43}$ B. Seidman and A. Seidman, State and Law in the Development Process: Problem-solving and Institutional Change in the Third World, 1994. 
if laws are not published they cannot be commented on. Such very basic issues determine whether a legal system can function at all or whether it cannot. ${ }^{44}$

Likewise, formal legality is associated with the down to earth issue as to whether the law is known by those it addresses. This ranges from the most basic means as the 'drug is against the law' signs on Jakarta airport, via comics explaining rights on land to indigenous groups to the availability of legal assistance, notably for the poor and disadvantaged. It is formal legality that thus provides the first direct link between the state-centred rule of law concept with the citizen-centred access to justice approach.

\section{Democracy}

While the previous elements in this category have been more or less generally accepted as essential elements for the rule of law, democracy is much less acclaimed as such. Although few will deny that democracy and rule of law are closely linked - for instance, in many countries it is common to speak of the 'democratic Rechtsstaat and not the Rechtsstaat on its own - many will not include democracy as an element of a rule of law definition.

This has both a theoretical and a practical side. First, democracy is sometimes used in order to add a substantive element to the list of formal requirements. It argues that laws will be just if they are informed by general consent. The most sophisticated version of this argument has been made by Habermas, whose argument is that in the absence of natural law democratic procedures are the only guarantee to just law we have. While there may be some truth in this, democracy is in the end only a procedure, which can never guarantee a substantially just outcome. Tamanaha has pointed out that for this reason democracy remains an 'empty' concept and moreover that democracy may yield very unfair laws. ${ }^{45}$

The practical reason not to include democracy into a rule of law concept is that if one intends to say something about the rule of law in a country, this makes it even a more daunting task than it already is if a more limited definition of rule of law is used. Democracy is a huge field of research on its own and one easily overburdens oneself by including it in the concept and then attempts to say something useful about the rule of law in a particular country. Within political science and development studies it has its own place and this is another practical reason not to bring it under the rule of law banner.

Nonetheless, if we return to the functions the rule of law serves, it is clear that democracy - at least liberal democracy - also serves the function of protecting

\footnotetext{
${ }^{44}$ See, for instance, on Indonesia G. Churchill, The Development of Legal Information Systems in Indonesia, 1992, Leiden: Van Vollenhoven Institute for Law and Administration in Non-Western Countries, Research Report no. 1.

45 Tamanaha, On the Rule of Law, pp. 99-101.
} 
citizens against the state. Making the government responsive to citizens is also a means of constraining its power, ${ }^{46}$ while a strong argument can be made that the opportunity democracy offers citizens to pursue their goals by electoral means is likely to reduce infringement on their fellow citizens' rights and property. ${ }^{47}$ Democracy's means, however, are not legal in the first place, but political - although democratic rules are somehow cast into law as well and there is an empirical relationship between democracy and respect for human rights. ${ }^{48}$ If one uses the rule of law as an ideal to pursue or as an inventory of means to control the state, then it does make sense to include it. Moreover, in order to be effective, democracy needs many of the checks implied in the elements previously dealt with, as well as the fundamental freedoms that will be addressed in the next category. ${ }^{49}$

One may also want to read a more limited form of democracy into the rule of law concept. This looks at the more local level of law formation and government decision-making and the influence citizens can have on those laws that directly affect them. An example of such a use of the concept would be procedures for participation in drafting a spatial plan or the principle that a citizen is heard before a legal decision is taken by the government that will affect him or her. In the latter example democracy is translated into a procedural device, which comes close to the principles of good government used to limit the exercise of governmental discretion.

\section{$2^{\text {ND }}$ Category: Substantive Elements}

- Subordination of all law and its interpretations to fundamental principles of justice

- Protection of individual rights and liberties

- Furtherance of social human rights

- Protection of group rights

\section{Subordination of all law and its interpretations to fundamental principles of justice}

Where the previous category was concerned with procedures in order to prevent misuse of power, this category does the same by introducing substantive standards. Although no part of thin definitions of the rule of law, this mechanism

${ }^{46}$ Cf., L.J. Diamond, Developing Democracy: Toward Consolidation, 1999, at p. 3.

47 This, one could argue, caused the split between 'revisionist' social-democrats and radical socialists preaching the revolution.

${ }^{48}$ Diamond, Developing Democracy: Toward Consolidation, at p. 5.

${ }^{49}$ See, for instance, G. O'Donnell, 'Why the Rule of Law Matters', 15 Journal of Democracy 4 (2004), pp. 32-46. 
goes back as far as the history of the rule of law. Both the Greek and the Romans knew it in the form of natural law. In fact, it is not difficult to relate the decline of this standard to the decline of natural law and the ascent of positive law theories.

However, many who do not subscribe to natural law theories still recognise substantive elements as part of the rule of law. The most 'relative' of such elements consists of principles of justice, morality, fairness and due process. These vary from one place to the other and over time and thus allow for a contextual interpretation. Peerenboom has observed that even the thinnest rule of law versions include a form of substantive 'context', which could be brought under this element. ${ }^{50}$ This also makes them useful for settings where customary law holds sway, as one can judge the system by its own terms.

The relativity of this approach is at the same time what makes it most vulnerable to abuse. It is not always easy to define what are to be regarded as fundamental principles in a given social field - certainly not when it concerns a state that is culturally diverse. Even in smaller and more homogeneous settings it may be difficult to determine which principles are so widely shared that they qualify as yardsticks for evaluating acts of authorities. This is a problem legal anthropologists have been accustomed to dealing with, but the carefulness and time required for this purpose are often beyond the capacity of those who have to test whether indeed the authorities have abided by them. On the other hand, if such principles can be determined they are likely to be more stable than democratic outcomes, as the latter will be susceptible to rapid political changes.

One may also add that this element is of vital importance to the legitimacy of the legal system in the eyes of a state's citizens. No matter how well procedural elements' prescriptions are followed, they cannot guarantee a substantively just outcome of the law's application. ${ }^{51}$ And if many consider the outcomes of the law as unjust the entire system may be endangered.

\section{Protection of individual rights and liberties}

Included by many into their rule of law definition, human rights to a large extent subsume aspects of the previous category, translated into such rights as fair trial. Accepted by almost all the states in the world and with some of them considered as international customary law, individual rights and liberties are less flexible than the principles of justice and morality discussed above, which is at the same time an advantage and a disadvantage. The growing body of anthropological literature on human rights reveals the importance of contextualising them when using them

\footnotetext{
${ }^{50}$ Peerenboom, 'Varieties of Rule of Law', pp. 5-6.

${ }^{51}$ Cf., Nonet and Selznick's idea of 'responsive' law (above).
} 
as a yardstick for state behaviour ${ }^{52}$ and this argument is equally applicable to their use within a rule of law framework.

Perhaps the main reason to include human rights generally into the rule of law framework is that this field has become the central rallying theme of development co-operation and that gradually it has become clear that in order to achieve any improvement in the realisation of human rights - whether it concerns the right to press freedom or to food - one needs an effective legal system to achieve this. Bringing the two together into one concept creates a shorthand and an ideal that is easy to be used to refer to human welfare and the legal framework required to achieve this.

We should further be aware that the neoliberal ideology underlying most of the activities of organisations such as the World Bank makes it very attractive to pursue this agenda under the rule of law aegis. As already mentioned earlier in this essay, international donors tend to subscribe to a very limited definition of rule of law, which emphasises rights to property, freedom of contract and the legal mechanism to enforce these. ${ }^{53}$ Faundez has pointed at the problems caused by notably the World Bank's failure to adequately address the relation between the development goals pursued and the legal framework. ${ }^{54}$ Including human rights into the definition of rule of law in the end may work out beneficially, as it should force donor organisations and scholars to think through carefully the relations between human rights and legal institutions. However, that does imply a broader conception of human rights than the one picked by the World Bank.

A disadvantage of including human rights into the definition of the rule of law has already been discussed in the context of democracy: it is such a vast field of its own that including it makes it difficult to say something 'general' about the rule of law. On the other hand, the direct relation between such fundamental freedoms as speech, assembly, fair trial, etc. to elements of the formal category is quite clear and does merit attention. ${ }^{55}$

\section{Furtherance of social human rights}

While human rights are to be found in most current rule of law definitions, this is certainly not true to the so-called 'social' human rights. This is not surprising, as

${ }^{52}$ See, e.g., M. Goodale, 'Introduction: Locating Rights, Envisioning Law Between the Global and the Local', in M. Goodale and S.E. Merry, The Practice of Human Rights: Tracking Law Between the Global and the Local, 2008, pp. 1-38 and S.E. Merry, Human Rights and Violence against Women, 2005.

${ }^{53}$ Ohnesorge, 'The Rule of Law, Economic Development and Developmental States in Asia'.

${ }^{54}$ Faundez, 'The Rule of Law Enterprise - Towards a Dialogue between Practitioners and Academics', pp. 5-8.

55 As suggested by one anonymous reviewer, it would make sense to actually develop a subcategorization of those human rights which are particularly connected with the rule of law. 
they are not directly concerned with preventing misuse of power in the way all elements mentioned so far have been: these rights creates the much further reaching obligation for the state to use its power for the benefit of its citizens, giving them a right to food, shelter, education, etc. Whether such needs should be formulated in the form of rights is a question often debated, but practically speaking more or less settled in favour with the adoption of these rights into international rights treaties and many constitutions worldwide.

An important definition incorporating these 'second generation' human rights is the one formulated by the International Commission of Jurists at its 1959 congress:

'The rule of law does indeed safeguard and advance the civil and political rights of the individual in a free society; but it is also concerned with the establishment by the state of social, economic, educational and cultural conditions under which man's legitimate aspirations and dignity may be realized. Freedom of expression is meaningless to an illiterate; the right to vote may be perverted into an instrument of tyranny exercised by demagogues over an unenlightened electorate; freedom from government interference must not spell freedom to starve for the poor and destitute.'

The strongest argument for including social rights into a rule of law definition is the second one: other parts of the rule of law can only function effectively if social rights are fulfilled and therefore a rule of law definition without makes little sense for the poor and disadvantaged.

This approach is strongly contested by Tamanaha, who has argued that the rule of law tends to lose all of its analytical value if it is taken as broadly as this. ${ }^{56}$ While there is some truth to this, on the other hand the rule of law concept at present is not very analytically effective at all given the diversity of definitions. In other words, one is always required to define the rule of law clearly before it can be deployed for this purpose. If, on the other hand, the rule of law is used as a kind of legal system's ideal, guiding programs and people towards a better future, then an all-encompassing notion may provide an effective shorthand for a whole field of mechanisms and ideas potentially contributing to serve the two functions of protecting citizens against the state and protecting citizens from one another. The flipside of this is obviously that it loses almost all of its analytical value.

\section{Protection of group rights}

The argument against including social human rights into one's rule of law definition applies even more strongly to this one. Not many defining the rule of law

${ }^{56}$ Tamanaha, On the Rule of Law, p. 113. 
include group rights into their concept, as these are controversial to qualify as human rights. ${ }^{57}$

On the other hand, some do, and it seems easier to fit them into a rule of law definition than the previous category. Group rights are by their nature closer to individual rights and liberties than social rights, in the sense that they aim to restrain the state from interfering with the private sphere of certain groups of citizens, whereas social rights are concerned with the active exercise of power by the state to promote citizens' welfare. Only if they are understood as implying the duty for the state to actively promote them this changes. An example of the latter interpretation would be to require the state to provide funds for supporting the use of certain languages rather than just allowing groups to use these languages for official communication. The most convincing reason to include group rights into a rule of law concept is that such rights can be a powerful weapon against the state's encroachment on citizens' rights or of other citizens, most likely in the form of large companies, doing the same. The gross injustices committed in this way against indigenous or other groups provide compelling reasons to look at group rights in the attempt to realise the functions pursued by the rule of law.

\section{$3^{\text {Rd }}$ Category: Controlling Mechanisms (Guardian Institutions)}

- An independent judiciary (sometimes broadened to trias politica)

- Other institutions charged with safeguarding elements of the rule of law

\section{An independent judiciary}

As already outlined above, independence of the judiciary is usually listed as a formal element of the rule of law, but its institutional nature in my view makes it more apt to be discussed under a separate heading. One may add that the judiciary is not only concerned with safeguarding the formal elements in the rule of law. This is not only empirically the case: as any scholar of courts can tell us judges will use all kinds of mediatory techniques to attain an outcome that is acceptable to the parties to a dispute. It is commonly accepted among legal theorists that judges should try to achieve an outcome that is substantively jus $\mathrm{t}^{58}$ - and obviously they should also take into account human rights. The judiciary does not limit itself to controlling whether the government has taken into account the formal elements

${ }^{57}$ E.g., A. Kuper, 'The Return of the Native', 44 Current Anthropology 3 (2004), pp. 389-402. Still there are many references to group rights as part of the rule of law, most of which see it as a natural extension of the concept. See, for instance, I. Brownlie, 'Rights of Peoples in Modern International Law', Bulletin of the Australian Society of Legal Philosophy, Special Issue: The Rights of Peoples, 1985, at pp. 105-106.

${ }^{58}$ The most prominent representant at present obviously being Dworkin. 
of the rule of law. Moreover, unlike the formal and substantive elements discussed sofar, the judiciary is an actor, whose task it is to guarantee that the government and citizens obey the limitations set to their exercise of power. It therefore makes sense to coin a separate 'actor' category consisting of controlling mechanisms.

Coincidentally, the independent judiciary is also less old than the other elements discussed in the formal elements category. Although the distrust Plato and Aristotle harboured against democracy already points at the need for an independent authority to apply the law, it is not until Montesquieu that this was fully reasoned through. Following Montesquieu, some theoreticians even go beyond independence of the judiciary and also include the separation between executive and legislature into their rule of law definition.

In spite of this relatively 'novel' origin, accounts of legal processes in $17^{\text {th }}$ century England by such historians as Hay and Thompson show how important even before Montesquieu the idea of an independent judiciary was to the rule of law. The main insight from their analysis in this context is that application of a law that is skewed in favour of the ruling classes obviously leads to unfair results, but that this can be mitigated by an independent judiciary which may ensure that the law will at least occasionally also work against individuals from this ruling class - evidenced by the (rare) death penalties imposed upon noblemen stretching the borders of their privileged position too far. ${ }^{59}$

An independent judiciary is part of virtually every definition of the rule of law, except for those subscribed to by authoritarian countries such as Vietnam or China. These argue that the judiciary should always serve the interests of the state, which objective is not different from non-authoritarian states, but then they assume the state to be synonymous with the executive. However, aside from this view an independent judiciary is generally subscribed to as an essential element of the rule of law.

The fact that definitions always speak about independence of the judiciary instead of impartiality reflects the priority most rule of law definitions still attribute to the protection of citizens against the executive (and to a lesser extent the legislature). Independence is the means through which impartiality should be achieved, the latter an issue on which surprisingly little theoretical literature is available. ${ }^{60}$ This cannot be said about the independence itself, which has been central to analyses

${ }^{59}$ D. Hay, 'Property, Authority and the Criminal Law', in P. Beirne, and R. Quinney, Marxism and Law, 1982, pp. 103-129.

${ }^{60}$ Exceptions are C.M. Larkins, Judicial Independence and Democratization: A Theoretical and Conceptual Analysis', 44 The American Journal of Comparative Law (1996) and P.H. Russell and D.M. O'Brien, Judicial Independence in the Age of Democracy: Critical Perspectives from around the World, 2001. 
made by such diverse persons as political philosophers and legal reform practitioners' toolkit makers. While most of this literature is concerned with state courts, others have taken up the issue of independence in relation to mediation and other forms of dispute resolution, which usually results in warnings for power disparities between the parties to a dispute. ${ }^{61}$

If they are to be effective, judiciaries must not only be independent but also accessible, their second quality required by this element. This means that the entire debate about 'access to justice' and how it can be achieved becomes relevant in the rule of law context. As most of this literature is indeed concerned with access to courts, this makes sense. The more recent turn that access to justice is conceived of as access to a much broader range of institutions, including nonstate ones, points at two issues relevant to this discussion: first, that the judiciary does not have a monopoly on justice, and second, that the relation between the judiciary and other dispute resolvers is also relevant to debates about the rule of law. Nonetheless, few would argue that in the end an independent judiciary could be dispensed with. ${ }^{62}$

While regarding all elements discussed so far their strictly 'legal side' seemed to be at least as important as the empirical one, both independence of and access to the judiciary is more of an empirical issue. This is somehow reflected in the general trends in legal reform in developing countries. These used to be focused primarily on lawmaking and legal education, but have since increasingly shifted to court reform and more recently access to justice - thus paying more attention to the structural and practical issues involved.

\section{Other guardian institutions}

Growing complexity in state organisation has led to increasing specialisation in performing state functions and this trend has extended to the institutional side of some rule of law definitions. The past years have seen a spectacular growth in 'guardian institutions', charged with safeguarding particular aspects of the rule of law. A good example is national human rights institutions, whose number has increased from only a few about twenty years ago to 120 at present. ${ }^{63}$ Another

${ }^{61}$ Probably the champion of such writing, both of courts and alternative dispute resolution is Mark Galanter. Important examples of his work on this issue are M. Galanter, Why the "Haves" Come Out Ahead: Speculations on the Limits of Legal Change', 9 Law \& Society Review (1974), pp. 95-160 about courts, M. Galanter \& J.K. Krishnan, "Bread for the Poor": Access to Justice and the Rights of the Needy in India', 55 Hastings Law Journal (2004), pp. 789-834 about ADR in India.

${ }^{62}$ See for an overview of the access to justice literature, R. Sandefur, 'Access to Civil Justice and Race, Class and Gender Inequality’, 34 Annual Review of Sociology (2008), pp. 339-358.

${ }^{63}$ For a list see http://www.nhri.net/nationaldatalist.asp, accessed on 21 April 2009. 
important institution is the Ombudsman, which has found its way into many systems, but one can think of many other institutions overseeing state actions. ${ }^{64}$

The reason to include them in rule of law definitions is that in many cases the judiciary alone is not sufficient to protect citizens, which is a logical result of the rise of the welfare state. Another particular feature of these institutions is that they are very much the outcome of international or transnational processes. Thus, national human rights institutions have been promoted heavily by the UN, while Ombudsmen have been adopted by many countries from the Scandinavian model, adapted to their own national circumstances.

An interesting feature of such institutions is moreover that they are sometimes introduced to replace a malfunctioning judiciary. Even if there is no doubt that an independent judiciary remains at the core of controlling the executive, in certain situations and fields their role has been taken over at least in part by Ombudsmen, National Human Rights Committees, Anti-Corruption Courts, etc. - either as a temporary measure or permanently. Hence, although they are not often explicitly mentioned as a part of the rule of law they have become very important in realizing the first function of the rule of law in particular in many places and therefore ought to be paid due attention.

\section{The Elementary Model as a Research Tool}

After this elaboration on the categories and the elements within them, this section offers a first step towards using this model for research. Its aim is not to provide an exhaustive list of 'rule of law indicators', but rather practical guideline for those who want to do rule of law-related research (although it may be helpful in assessing rule of law indicators schemes). It may also serve to sensitise researchers to certain instruments used to curb government power or to provide ideas for those who want to make policy recommendations on this issues.

The model is of an interdisciplinary nature since the research questions look at the elements from both a legal and an empirical perspective. The empirical questions are indispensable to obtain reliable information about the state of certain elements. For instance, if we are talking about the independence of the judiciary, one should know about the conditions under which judges perform their tasks in order to assess whether they are effectively independent or not. Thus, how are judicial careers managed in practice, are judges exposed to terror, do they get to know the results of appeals against their judgments, etc. The result is an understanding of the relation between rule of law elements and contextual factors which is lacking in much research. The approach thus tries to accommodate Martin

\footnotetext{
${ }^{64}$ This includes election committees, anti-monopoly institutions, bodies overseeing fair trade practices, commissions supervising the legality of operations of intelligence agencies, etc.
} 
Krygier's observation that 'the institutionalised norms need to count as a source of restraint and a normative resource, usable and with some routine confidence used in social life. ${ }^{95}$

$1^{\text {st }}$ Category: Procedural elements - Related research questions

Rule by law

- to what extent does the government operate without using law?

- to what extent does the government use incidental measures instead of general rules?

- to what extent does the government regulate the relations between its subjects by law?

- to what extent are these laws followed?

State actions are subject to law

- to what extent does the law leave room for so-called 'vrij bestuur', 'discretionary powers'?

- are there exception clauses, allowing for special measures?

- does the government in effect base its actions on law (i.e. does the government operate outside the law)?

\section{Formal legality}

- are laws juridically clear?

- are there retroactive laws?

- are there any exceptions in legislation?

- are laws stable (not changed all the time)?

- are laws applied generally (without discrimination)?

- are laws accessible:

a) are laws published?

b) are laws written in comprehensible language?

c) are laws socialised?

\section{Democracy}

- are there any mechanisms for stakeholder participation in making regulations?

- are there any mechanisms for stakeholder participation in making individual decrees?

- are these mechanisms accessible?

- are they effective?

${ }^{65}$ Krygier, 'The rule of Law: Legality, Teleology, Sociology', at p. 60. 
$2^{\text {nd }}$ Category: Substantive elements - Related research questions

Subordination of all law and its interpretations to fundamental principles of justice

- what are the applicable written principles of justice and of proper administration?

- what are the applicable unwritten principles of justice and of proper administration and moral principles?

- to what extent are these conflicting?

- to what extent are law and its interpretations effectively subordinated to these principles?

\section{Protection of individual rights and liberties}

- to what extent are these legally guaranteed (including the question to what extent they apply in the relations between citizens)?

- to what extent are these legal guarantees implemented?

Furtherance of social human rights

- to what extent are these legally guaranteed?

- to what extent are these legal guarantees implemented?

Protection of group rights

- to what extent are these legally guaranteed?

- to what extent are these legal guarantees implemented?

$3^{\text {rd }}$ Category: Controlling mechanisms - Research questions

There exists an independent judiciary

- is there an independent judiciary (i.e. tenure security, issues of court management, etc.)?

- is the judiciary impartial (i.e. are there sufficient guarantees for 'insulation' from outside pressure in a given case)?

- do citizens have effective access to the judiciary (in terms of standing, distance from the court, costs, knowledge, legal aid, etc.)?

- do citizens get a fair and timely hearing by the court?

- does the judiciary dispose of adequate jurisdictionary and remedial powers?

- are judgments implemented?

There are other institutions charged with safeguarding elements of the rule of law

- are there such institutions and what is there legal mandate?

- how do they perform their functions and are they effective? 


\section{Concluding Remarks}

This essay has attempted to elaborate and further systematise the approaches by Peerenboom and Tamanaha to 'dissect' the rule of law concept into elements, using the distinctions between 'thin' and 'thick' and between 'formal' and 'substantive' as points of departure. This has yielded a framework that hopes to contribute to conceptual clarity, assisting participants to rule of law debates to specify more clearly what they are discussing. Moreover, it allows for meaningful comparison between various systems, as unlike their elements these systems in their entirety often are incommensurable.

The model can also be used in another way. Because it takes the two basic functions of protecting citizens against the state and protecting citizens from one another as its point of departure, it can be helpful in realising the teleological and sociological approach in rule of law research promoted by Krygier. ${ }^{66}$ While Krygier suggests to start with a clean slate, so to say, instead of adopting the 'juristic anatomy', I think it makes sense to use this 'anatomy' as a first point of attention for researchers interested in ways to realise the rule of law functions. However, one should not stop there and always be on the lookout for alternatives and other constructions and options which may help realise these functions.

This framework may thus also help to underline the relevance of rule of law in the context of alternative normative orderings, for instance as based on Islamic or 'traditional' law. Rule of law elements may also be relevant in checking the exercise of power in such non-modern state settings. Given the decline of many strong states and the resurgence or reinvention of traditional (customary) structures and other forms of normative ordering this seems particularly relevant. Empirical research in this field may also help to assess whether or not certain rule of law elements have universal value in curbing the use of power and to what extent alternative mechanisms are in place. The result is that rule of law elements can be evaluated in their context and that discarding an element in a certain context does not necessarily lead to refuting the entire rule of law concept. Once again, I want to underline that the objective of this framework is not to offer a definition, but only to provide potential elements for it.

The main practical reason for this whole exercise has been my experience that in research projects concerning rule of law issues it is hard to find a 'common language' to discuss them. This has also been the incentive to develop some questions for each element. The present essay has started as a very short, practical internal memo for those involved in a research project carried out at the Van Vollenhoven Institute and gradually evolved into something more. It has proven

${ }^{66}$ See Krygier, 'The rule of Law: Legality, Teleology, Sociology'. 
its use in this project and that has been an important reason to eventually communicate it to a wider public.

As all conceptual frameworks, this one will suffer from shortcomings and must be seen as a start rather than an accomplished research tool. An obvious next step would be to think through the relation of the various elements listed - and potential additions - to the two functions set out at the start. Not all elements are equally important for realising each of these functions. Secondly, the research questions should clearly be developed further. They can, however, be built on and can be further developed on the basis of socio-legal research. Likewise, one can think about adding a special actor category for the executive, which - unlike the judiciary - is never included separately into rule of law definitions. Still, my hope is that in its present form this model may already contribute to locating and organising information about rule of law practices that is now often scant, scattered and unsystematic. 